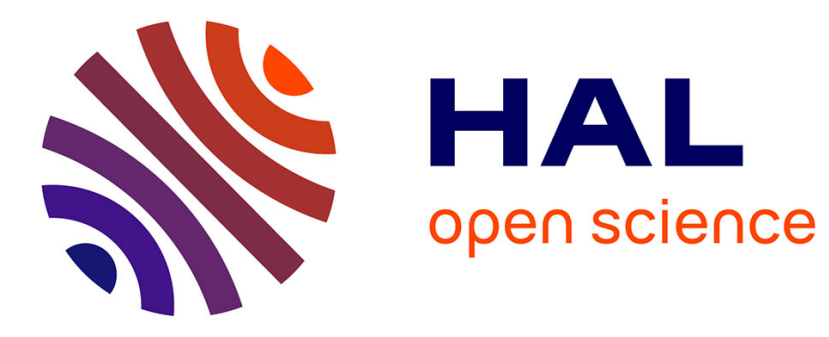

\title{
Partitioning of microbial cells between clouds and precipitation
}

Raphaëlle Péguilhan, Ludovic Besaury, Florent Rossi, Jean-Luc Baray, Thibaud Mas, Laurent Deguillaume, Barbara Ervens, Pierre Amato

\section{- To cite this version:}

Raphaëlle Péguilhan, Ludovic Besaury, Florent Rossi, Jean-Luc Baray, Thibaud Mas, et al.. Partitioning of microbial cells between clouds and precipitation. EGU General Assembly 2020, May 2020, Vienne, Austria. 10.5194/egusphere-egu2020-2876 . hal-03004047

\section{HAL Id: hal-03004047 https://hal.science/hal-03004047}

Submitted on 13 Nov 2020

HAL is a multi-disciplinary open access archive for the deposit and dissemination of scientific research documents, whether they are published or not. The documents may come from teaching and research institutions in France or abroad, or from public or private research centers.
L'archive ouverte pluridisciplinaire $\mathbf{H A L}$, est destinée au dépôt et à la diffusion de documents scientifiques de niveau recherche, publiés ou non, émanant des établissements d'enseignement et de recherche français ou étrangers, des laboratoires publics ou privés. 
EGU2020-2876, updated on 13 Nov 2020

https://doi.org/10.5194/egusphere-egu2020-2876

EGU General Assembly 2020

(c) Author(s) 2020. This work is distributed under

the Creative Commons Attribution 4.0 License.

\section{Partitioning of microbial cells between clouds and precipitation}

Raphaëlle Péguilhan ${ }^{1}$, Ludovic Besaury ${ }^{1}$, Florent Rossi ${ }^{1}$, Jean-Luc Baray ${ }^{2}$, Thibaud Mas ${ }^{3}$, Laurent Deguillaume $^{2}$, Barbara Ervens ${ }^{1}$, and Pierre Amato ${ }^{1}$

'Université Clermont Auvergne, CNRS, SIGMA Clermont, ICCF, F-63000 CLERMONT-FERRAND, FRANCE

(raphaelle.peguilhan@uca.fr)

${ }^{2}$ Université Clermont Auvergne, CNRS, OPGC, F-63000 CLERMONT-FERRAND, FRANCE

${ }^{3}$ Université Clermont Auvergne, CNRS, Laboratoire Microorganismes : Genome et Environnement, F-63000 CLERMONT-

FERRAND, FRANCE

It is known that microorganisms are present in the outdoor atmosphere, in clouds and precipitation. These microorganisms originate from various local and distant sources and consist of very diverse and ephemeral communities. The most abundant bacterial taxa typically include Alpha-, Beta- and Gamma-Proteobacteria, with notably Pseudomonas and Sphingomonas among the dominant genera observed. Still, very little is known about their sources, metabolic activity, distribution, and their dynamics during their atmospheric life cycle. It was proposed in the past that bacteria with high ice nucleation activity are likely more efficiently precipitated than others [1]. Here, we extend this hypothesis and suggest more generally that different bacteria taxa could exhibit different phase partitioning between aerosol particles, cloud and rainwater, which may affect their atmospheric residence times. This implies that microorganisms are not equally distributed among the different atmospheric compartments (clouds, aerosols and precipitation).

To investigate this hypothesis, cloud and rain samples were collected simultaneously from single precipitation events, from two meteorological stations located at different altitudes: the summit of puy de Dôme Mountain (1465 m above sea level; France), embedded in clouds, using cloud impactors and high-flow-rate impingers [2], and below the summit, at Opme Station (680 a.s.l.) where precipitation occurred, using automated precipitation collector. The bacterial biodiversity was examined by $16 \mathrm{~s}$ rRNA gene amplicon MiSeq sequencing. Samples were also characterized for their chemical contents. We show that clouds and precipitation host distinct microbial communities. Clouds host communities from high altitude likely to be of distant origin, while precipitation also includes material originating from the air column underneath and from local origin. So, comparing the biodiversity hosted in clouds and precipitation within single air masses provides information on the relative contribution of local and distant sources to the microorganisms deposited at the surface with rainfalls, and provides very new information concerning the processing and fate of bacteria in the atmosphere.

[1] M. Joly, P. Amato, L. Deguillaume, M. Monier, C. Hoose, and A. M. Delort, "Quantification of ice nuclei active at near $0{ }^{\circ} \mathrm{C}$ temperatures in low-altitude clouds at the Puy de Dôme atmospheric 
station," Atmos. Chem. Phys., vol. 14, no. 15, pp. 8185-8195, 2014.

[2] T. Šantl-Temkiv et al., "High-Flow-Rate Impinger for the Study of Concentration, Viability, Metabolic Activity, and Ice-Nucleation Activity of Airborne Bacteria," Environ. Sci. Technol., vol. 51, no. 19, pp. 11224-11234, 2017. 